\title{
Didymosperma gracilis, a new synonym of Wallichia nana (Arecaceae)
}

\author{
Mehmud S. * H. Roy \\ Department of Botany, Cotton University, Panbazar, Guwahati, Assam - 781 001, India \\ ${ }^{\star}$ E-mail: mehmudselim@gmail.com
}

\begin{abstract}
Didymosperma gracilis Hook.f. is merged here as a synonym of Wallichia nana Griff. based on examination of the protologue, type materials and fresh collections. Both are similar in their habit, habitat, size and nature of leaflets and fruits.
\end{abstract}

Key words: Nomenclature, Northeast India, Palm.

\section{Introduction}

All species of Didymosperma H.Wendl. \& Drude ex Hook.f., except Didymosperma gracilis Hook.f., were either placed under Arenga Labill. ex DC. (Mogea, 2004; www.theplantlist.org) or Wallichia Roxb. (Henderson, 2007, 2009; www.theplantlist. org). Henderson (2007) revised the genus Wallichia and raised the question of the existence of the species D. gracilis as he not only mentioned the name under "excluded and doubtful names", but also stated that "The type specimen is so poor that it is not possible to identify this specimen". Out of eight species of Wallichia (Henderson, 2007), five species are found in India (Renuka \& Sreekumar, 2012; Mehmud \& Roy, 2020). Three species occur in Assam (Mehmud \& Roy, 2021). Whereas Arenga is represented by 24 species (Pillai et al., 2020) with five species in India. Northeast India harbours three species viz. A. micrantha C.F.Wei from Sikkim and Arunachal Pradesh, A. obtusifolia Mart. from Arunachal Pradesh, and A. westerhoutii Griff. from Arunachal

Received: 26.01.2021; Revised \& Accepted: 13.05.2021 Published Online: 30.06.2021
Pradesh and Manipur (Renuka \& Sreekumar, 2012). Only A.westerhoutii was recorded so far from Assam (Barbhuiya, 2014; Mehmud \& Roy, 2021). All these three species of Arenga in northeastern India bear linear leaflets and their diameter of stem ranges from 13-60 cm (Renuka \& Sreekumar, 2012).

Didymosperma gracilis was described by Hooker (1894) based on Booth's collection from Daphla Hills in Assam (now Dafla Hills in Arunachal Pradesh). The type specimen at K (K000400178 digital image!) has a part of stem with two leaves, incomplete or damaged, fibrous ligule and alternate, serrated, abaxially white leaflets. The apical leaf near the fruiting branch is comparatively shorter than the other leaves. The fruiting branch is terminal, with three rachillae, having few elliptic-oblong fruits having persistent perianth and acute lobes and brown, elliptic-curved or concavo-convex seeds. The information associated with the protologue and type material of $D$. gracilis is not matching with any species of Arenga, but shows perfect match with the protologue of Wallichia nana Griff. (Griffith, 1845) and information related to types (Griffith, 1850; Henderson, 2007; Reveal \& Nixon, 2013), especially when features of the stem, leaf, fruit and seed are compared. Moreover, the taxonomic description and note added to $W$. nana in relevant studies (Henderson, 2007; Renuka \& Sreekumar, 2012; Mehmud \& Roy, 2020, 2021), and examination of the fresh collections in different stages (Fig. 1) in the present study gives additional support to consider Didymosperma gracilis as a synonym of Wallichia nana. 


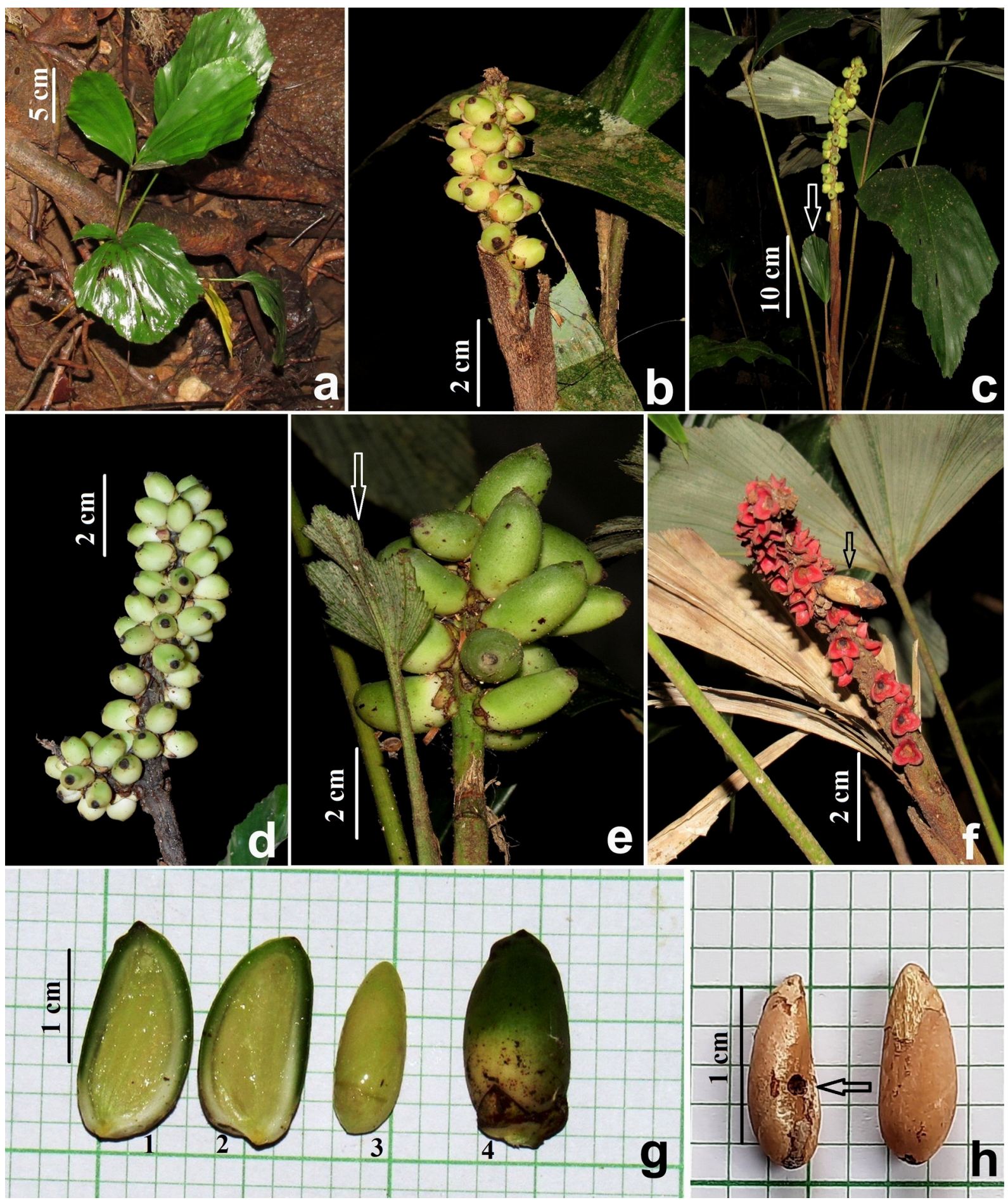

Fig. 1. Wallichia nana Griff.: a. Young plant; b-d. Young fruits (arrow showing small leaf); e. Small leaf near the infructescence (arrow); f. Infructescence with dry fruit (arrow) and persistent perianth; g. Longitudinal cut of an immature fruit (1 \& 2), seed (3) and a complete fruit (4); h. Dry seeds with embryo in central position (arrow).

\section{Taxonomic Treatment}

Wallichia nana Griff., Calcutta J. Nat. Hist. 5: 488. 1845. Harina nana (Griff.) Griff., Palms British East India 176. 1850. Didymosperma nanum (Griff.)
H.Wendl. \& Drude in Kerchove, Palmiers 243. 1878. Blancoa nana (Griff.) Kuntze, Revis. Gen. Pl. 2: 727. 1891. Arenga nana (Griff.) H.E.Moore, Principes 4: 114. 1960. Type: INDIA, Assam, s.d., 
Jenkins s.n. (A [00421704 digital image!], BH n.v., BR [BR0000006876920 digital image!, BR0000006877255 digital image!], K [K000400177 digital image!], L [0042007 digital image!], NY n.v., P [P00491422 digital image!]).

Didymosperma gracilis Hook.f., Fl. Brit. India 6(18): 420. 1894. Type: INDIA, Arunachal Pradesh, Dafla ("Daphla") Hills, s.d., Booth s.n. (holo K [K000400178 digital image!]). syn. nov. Fig. 1.

Specimens examined: INDIA, Arunachal Pradesh, Dibang valley, 26.03.1999, M. Bhaumik 2168 (ASSAM). Assam, Jorhat, Nambor R.F., 21.11.1964, S.K. Kataki 41649 (ASSAM 44563); Tinsukia, Bherjan, N 27³'27.2", E 95 22'14.4", alt. 84 m, 03.09.2019, Selim Mehmud 169 (ASSAM, Herbarium of Department of Botany, Cotton University); West Karbi Anglong, Nellie to Umapanai road, 13.02.2020, Selim Mehmud 242 (Herbarium of Department of Botany, Cotton University).

\section{Acknowledgements}

We are grateful to the Head of the Department of Botany, Cotton University. We are also obliged to the authorities of Assam Forest Department; Director of Botanical Survey of India for herbarium consultations (ASSAM and CAL); Dr. Sarah Phillips of Royal Botanic Gardens, Kew for providing high resolution images of the type of Didymosperma gracilis; and authorities of A, BR, L, NY, P for digital herbarium.

\section{Literature Cited}

BARBHUIYA H.A. 2014. Forty new additions to the angiospermic flora of Assam. Journal on New Biological Reports 3(3): 277-287.

GRIFFITH W. 1845. The palms of British East India. Calcutta Journal of Natural History 5: 1-103, 311-491.

GRIFFITH W. 1850. Palms of British East India: posthumous papers bequeathed to the Honourable the East India Company. Periodical Experts Book Agency, Delhi.

HENDERSON A. 2007. A revision of Wallichia (Palmae). Taiwania 52(1): 1-11. https://doi.org/10.6165/ tai.2007.52(1).1

HENDERSON A. 2009. Palms of southern Asia. Princeton University Press, United States of America.

HOOKER J.D. 1894. Flora of British India. Volume 6. L. Reeve \& Co. Ltd. The Oast House, Brook, Ashford, Kent.

MEHMUD S. \& H. ROY 2020. Anatomical studies on Wallichia nana Griff., a wild palm of Assam, India. Reinwardtia 19(2): 97-102. https://doi.org/10.14203/ reinwardtia.v19i2.3920

MEHMUD S. \& H. ROY 2021. Diversity and distribution of palms (Arecaceae) in Assam, India. Check List 17(1): 69-93. https://doi.org/10.15560/17.1.69

MOGEA J.P. 2004. Four new species of Arenga (Palmae) from Indonesia. Reinwardtia 12(2): 181-189. https:// doi.org/10.14203/reinwardtia.v12i2.67

PILLAI A.R., RIYAS C.T. \& K.K. SABU 2020. A review on the unexplored and underutilized Arenga species in India. Current Botany 11: 226-232. https://doi.org/ 10.25081/cb.2020.v11.6252

RENUKA C. \& V.B. SREEKUMAR. 2012. A field guide to the palms of India. Kerala Forest Research Institute, Peechi.

REVEAL J.L. \& K.C. NIXON. 2013. The palm type collection in the Liberty Hyde Bailey Hortorium (BH). Phytoneuron 79: 1-46. 